\title{
Records of Birds under Vulnerable and Near Threatened Category from the different Habitat around Yavatmal, Central India
}

\author{
Praveen Joshi
}

Department of Zoology, Amolakchand Mahavidyalaya, Yavatmal

\begin{abstract}
Based on five years an avian study of selected area has helps to make a bird list of Near Threatened (NT) \& Vulnerable (VU) category according to ENVIS Centre of Avian Ecology. Fifteen species were sighted during observations of different ecological habitat from which twelve birds are NT and three are VU. Out of fifteen ten are waders, three-raptors and two-passerine. It was noticed that Grey Headed Fish Eagle, Red Headed Falcon, European Roller, Indian Skimmer sighted only one time but Ferruginous Duck, Greater Thick-Knee, Pallid Harrier were two time. Curlew Sandpiper has sighted constantly three years and remaining all the species are observed every year during study period. This study will continue and in future, the number goes on increasing compare to the list of NT and VU species published by ENVIS.
\end{abstract}

Keyword- Near-Threatened species, Vulnerable species, Selected habitat, Different Habitat, Around Yavatmal.

\section{Introduction}

A taxon is Near Threatened when it has been evaluated against the criteria but does not qualify for Critically Endangered, Endangered or Vulnerable now, but is close to qualifying for or is likely to qualify for a threatened category in the near future. A taxon is Vulnerable when the best available evidence indicates that it meets any of the criteria A to E for Vulnerable (see Section V), and it is therefore considered to be facing a high risk of extinction in the wild. The present paper based on survey and observationary recorded of birds under these two categories from the selected area around Yavatmal city.

\section{Materials and Methods}

Study area includes seven fresh water resources- Nilona, Borgaon, Jamwadi, Arjuna, Bembla, Echori and Mandev.

Table 1: Classification of birds (NT-Near Threatened and VU- Vulnerable)

\begin{tabular}{|l|l|l|l|l|}
\hline S.No. & Common Name & Scientific Name & Family & Category \\
\hline 1 & Curlew Sandpiper & Calidris ferruginea & Scolopacidae & NT \\
\hline 2 & Oriental Darter & Anhinga melanogaster & Anhingidae & NT \\
\hline 3 & Painted Stork & Mycteria leucocephala & Ciconiidae & NT \\
\hline 4 & Black Headed Ibis & Threskiornis melanocephalus & Threskiornithidae & NT \\
\hline 5 & Ferruginous Duck & Aythya nyroca & Anatidae & NT \\
\hline 6 & Great Thick-Knee & Esacus recurvirostris & Burhinidae & NT \\
\hline 7 & River Tern & Sterna aurantia & Laridae & NT \\
\hline 8 & Asian Woollyneck Stork & Ciconia episcopus & Ciconiidae & VU \\
\hline 9 & Indian Skimmer & Rynchops albicollis & Laridae & VU \\
\hline 10 & Common Pochard & Aythya ferina & Anatidae & VU \\
\hline 11 & Grey Headed Fish Eagle & Ichthyophaga ichthyaetus & Accipitridae & NT \\
\hline 12 & Red headed Falcon & Falco chicquera & Falconidae & NT \\
\hline 13 & Pallid Harrier & Circus macrourus & Accipitridae & NT \\
\hline 14 & Alexandrine Parakeet & Psittacula eupatria & Psittacidae & NT \\
\hline 15 & European Roller & Coracias garrulous & Coraciidae & NT \\
\hline
\end{tabular}

It was noticed that some species like Grey Headed Fish Eagle, Red headed Falcon, European Roller and Indian Skimmer sighted only ones during study period. Ferruginous Duck, Greater Thick-Knee, Pallid Harrier were sighted twice
Four forest ranges- Umerda, Jam, Echori, Babhulgaon and seven grassland- Chausala, Berbada, Bahiram, Nilona, Echori, Bembla and Borgaon. Periodical visit were arranged to every habitat for last five years from March 2012 to December 2016. Nikon binocular 8X42 ranges was used for observation of habitat and Nikon digital camera (Coolpix) has been used to take visual records.

\section{Results and Discussion}

Study on NT and VU diversity have shows satisfactory results. Out of three hundred and seven visual records of birds from the selected habitat twelve Near-Threatened and three Vulnerable species of birds were identified and successfully take a visual records.(Table-1)

The list is as follows- but Curlew Sandpiper thrice in the five years. Remaining all the species have routinely observed from the areas. (Table2) 


\section{International Journal of Science and Research (IJSR) \\ ISSN (Online): 2319-7064 \\ Index Copernicus Value (2015): 78.96 | Impact Factor (2015): 6.391}

Table 2: Details of species sighted during the study period (N-No and Y-Yes)

\begin{tabular}{|c|c|c|c|c|c|c|c|c|c|c|c|c|c|c|c|}
\hline Study Period (Years) & \multicolumn{10}{|c|}{ Specis Sighted Number of Times } \\
\hline & 1 & 2 & 3 & 4 & 5 & 6 & 7 & 8 & 9 & 10 & 11 & 12 & 13 & 14 & 15 \\
\hline 2012 & $\mathrm{~N}$ & $\mathrm{Y}$ & $\mathrm{Y}$ & $\mathrm{Y}$ & $\mathrm{N}$ & $\mathrm{N}$ & $\mathrm{Y}$ & $\mathrm{Y}$ & $\mathrm{N}$ & $\mathrm{Y}$ & $\mathrm{N}$ & $\mathrm{N}$ & $\mathrm{N}$ & $\mathrm{Y}$ & $\mathrm{N}$ \\
\hline 2013 & $\mathrm{~N}$ & $\mathrm{Y}$ & $\mathrm{Y}$ & $\mathrm{Y}$ & $\mathrm{Y}$ & $\mathrm{N}$ & $\mathrm{Y}$ & $\mathrm{Y}$ & $\mathrm{N}$ & $\mathrm{Y}$ & $\mathrm{Y}$ & $\mathrm{N}$ & $\mathrm{Y}$ & $\mathrm{Y}$ & $\mathrm{N}$ \\
\hline 2014 & $\mathrm{Y}$ & $\mathrm{Y}$ & $\mathrm{Y}$ & $\mathrm{Y}$ & $\mathrm{N}$ & $\mathrm{N}$ & $\mathrm{Y}$ & $\mathrm{Y}$ & $\mathrm{N}$ & $\mathrm{Y}$ & $\mathrm{N}$ & $\mathrm{N}$ & $\mathrm{N}$ & $\mathrm{Y}$ & $\mathrm{N}$ \\
\hline 2015 & $\mathrm{Y}$ & $\mathrm{Y}$ & $\mathrm{Y}$ & $\mathrm{Y}$ & $\mathrm{Y}$ & $\mathrm{Y}$ & $\mathrm{Y}$ & $\mathrm{Y}$ & $\mathrm{N}$ & $\mathrm{Y}$ & $\mathrm{N}$ & $\mathrm{N}$ & $\mathrm{N}$ & $\mathrm{Y}$ & $\mathrm{Y}$ \\
\hline 2016 & $\mathrm{Y}$ & $\mathrm{Y}$ & $\mathrm{Y}$ & $\mathrm{Y}$ & $\mathrm{N}$ & $\mathrm{Y}$ & $\mathrm{Y}$ & $\mathrm{Y}$ & $\mathrm{Y}$ & $\mathrm{Y}$ & $\mathrm{N}$ & $\mathrm{Y}$ & $\mathrm{Y}$ & $\mathrm{Y}$ & $\mathrm{N}$ \\
\hline
\end{tabular}

The result indicates that Yavatmal city has surrounded by the variety of habitats also rich in ecological status and supports the birds to fulfill their demands so the diversity of bird species visited area according to their niche. Continue observations help to find the species who are facing the problems and stands under various category. Routine visits are made possible to records unexpected birds if they are visited the area. The search is continue and confident that list of birds under various category will be sighted in the area.

\section{References}

[1] Ali,s. (1996) :The Book of Indian Birds, 12th edn. New Delhi: BNHS \& OUP.

[2] Ali, S. \& Riplay,D.(1987): Hand book of the birds of India \& Pakistan, compact edn. Bombay:OUP

[3] Grewal, B. (2011): Birds of Indian sub continent (Third Edition) Hong Kong: Guide book co. Ltd.

[4] Grimmett, R., Inskipp C. and Inskipp, T. (2000) Birds oh Indian subcontinent. London.

[5] Grimmett, R., Inskipp C. and Inskipp, T. (2012) Birds oh Indian subcontinent. London.

[6] John Hendrickson (1992) Bird of Prey China.

[7] Manakdan Ranjit and Daniel J.C. et al (2011) Birds of Indian subcontinent A field Guide. Oxford University Press, USA.

[8] Martin Woodcock (1983) Collins Birds of India, Harper Collins UK.

[9] Otto pfister (2011) A Photographic guide of birds of India. Timeless book New Delhi.

[10]Rishad Naoroji (2012): Bird of prey of the Indian subcontinent, OM Book Service,India 